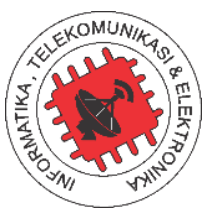

\title{
Analysis and Performance Comparison of Microwave and Wi-Fi 802.11ac Based Backhaul for Long-Term Evolution Network in Urban Area
}

\author{
Nida Nurvira ${ }^{1}$, Anggun Fitrian Isnawati ${ }^{2 *}$, Achmad Rizal Danisya ${ }^{3}$ \\ 1,2,3 Institut Teknologi Telkom Purwokerto \\ 1,2,3 Jalan D. I. Panjaitan, No.128, Purwokerto, Ja wa Tengah, Indonesia \\ *Corresponding email: anggun @ittelkom-pwt.ac.id
}

Received 12 December 2019, Revised 08 January 2020, Accepted 22 April 2020

\begin{abstract}
Increasing user requirements for LTE networks, data traffic from eNodeB to core network is also increases, therefore, the recommended solution for meeting this high data traffic is to use a backhaul network design. Backhaul is the path or network used to connect eNodeB with the core network. In this research, backhaul technology used is Wi-Fi 802.11ac backhaul and microwave backhaul. In this study begins by collecting existing data, then perform capacity calculations to find out the number of eNodeB needed and to find out the capacity of the backhaul links to be designed, then determine the antenna height to achieve LOS conditions, then calculate the desired performance standards and calculate the backhaul network link budget on microwave and Wi-Fi technologies. Based on the calculation results in terms of capacity, the total user target is 90,167 users and has a throughput capacity per eNodeB of $61 \mathrm{Mbps}$. In the link-capacity calculation, the total link capacity is $427 \mathrm{Mbps}$. From the simulation results that using microwave technology, the average RSL value is $-30.90 \mathrm{dBm}$, the value meets the $-57 \mathrm{dBm}$ threshold standard and the value of a vailability does not meet the standard of $99.999 \%$ because the average value obtained is $99.998095 \%$. Whereas for Wi-Fi technology, the average RSL value is $-39.24 \mathrm{dBm}$ and meet the $-72 \mathrm{dBm}$ threshold standard, for the avera ge availability value meets $99.999 \%$ standard, with a value of $100 \%$. From the results of the two technologies, can be conclude that the Wi-Fi technology is more suitable for the use of backhaul network design in Ciputat Sub-district.
\end{abstract}

Keywords - LTE, Backhaul, Wi-Fi 802.11ac, Microwave

Copyright @ 2020 JURNAL INFOTEL

All rights reserved.

\section{INTRODUCTION}

The technology development in the telecommunications industry is currently increasing so that a reliable network is required for high-speed data transfer. Technology that presently developed is the Long-Term Evolution (LTE) network. It has a data rate of up to $100 \mathrm{Mbps}$ for downlinks and 50 Mbps for uplinks [1]. With a high data rate, a backhaul network is needed for linking the eNodeB and the core network. Backhaul is a path that is connecting one site to the core network or from one site to a nother. In this research, a backhaul is designed using microwave and Wi-Fi 802.11ac technology. Microwave transmission data using a frequency of 2 $\mathrm{GHz}$ to $24 \mathrm{GHz}$ while 802.11ac Wi-Fi technology works at a frequency of $5 \mathrm{GHz}$ and has speeds of up to $1 \mathrm{Gbps}$.
Research [1] uses 802.11n Wi-Fi technology for backhaul networks. From the calculation results, the most effective scenarios for rural areas obtained by using $900 \mathrm{MHz}$ frequency and $5 \mathrm{MHz}$ bandwidth. Meanwhile, for the backhaul network the gain is greater than $75 \mathrm{dBm}$ and the availability value is greater than $99.99 \%$. Research [2] uses a microwave minilink device to serve as a backhaul network. This design uses two scenarios, and scenario 1 has chosen for the backhaul network design. The choice of scenario 1 is because it has more paths, so fewer failed packets have sent. Scenario 1 obtained an average free-space loss of $121.47 \mathrm{~dB}$, an average signal level of $-64 \mathrm{dBm}$, an average fading margin of $30.79 \mathrm{~dB}$, requires four hops and 64 backhauls minilink. In the research [3] regarding LTE-network design by utilizing Microwave as a backhaul network. Based on 
the data obtained, total LTE users are 47,324 users. For backhaul network design, seven hops backhaul has obtained using star topology, with a total link capacity of $936 \mathrm{Mbps}$ and at a frequency of $15 \mathrm{GHz}$. The calculation results from this design show the level of received power ranges from $-70 \mathrm{dBm}$ to $-75 \mathrm{dBm}$.

The purpose and aim of this research are to compare the backhaul performance between microwave and Wi-Fi 802.11ac technology for LTE communication in the Ciputat sub-district area. With the increasing number of cellular users in that area, it is supportive of the development of mobile technology. The result of this research is choosing the backhaul network design with technology that is more suitable for LTE communication using backhaul networks in the area.

\section{RESEARCH METHOD}

\section{A. Research Area}

In this study, the area used for backhaul network design is urban area and the area is in Ciputat subdistrict area, as shown in Fig. 1.

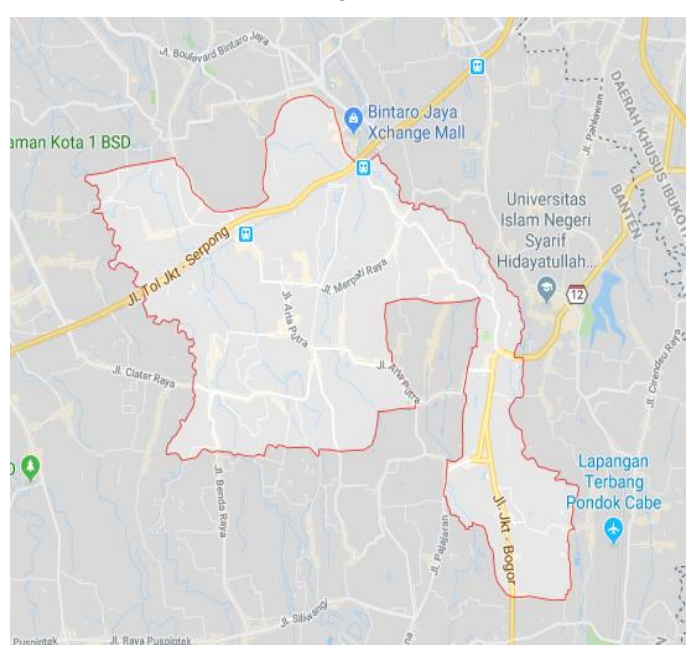

Fig. 1. Ciputat Sub-District Area [4]

\section{B. Planning Capacity}

The calculation based on capacity takes into consideration the number of users who will access eNodeB so that the value of the traffic needed for the LTE network in a known area. In this capacity calculation, there are several calculations performed as follows:

a) TotalUser Target

The parameter using in this research is based on the capacity parameter, namely, population, population growth rate, population of productive age, market share of operators, and LTE penetration in the regions used as a plan.

\section{b) Throughput per Session}

From some available services, the calculation of throughput per session is to obtain the value of throughput from the downlink and uplink sides of each service. c) Single-user Throughput

Single-user throughput is the value of throughput required by each customer. The value of single-user throughput is different in each region. This matter happens because the value of busy hour service attempts and the traffic penetration ratio in each area is different.

\section{d) Network Throughput}

The network throughput, both in terms of uplink and downlink, could be obtained by multiplying the estimated number of customers by the value of singleuser throughput.

\section{e) Cell Capacity}

Cell capacity is utilized to find out how much the ability of a cell to accommodate traffic. Its value influenced by several parameters, namely bandwidth, the type of modulation, code rate, and MIMO antenna used.

\section{f) eNodeB Number}

To calculate the number of eNodeB there are several parameters, namely, the width of the planned area and the number of customers contained in the area.

\section{Backhaul Network Design}

Network design in this backhaul network design makes comparisons using two technologies, namely Wi-Fi 802.1 lac backhaul and microwave backhaul. In these backhaul network design using chain topology and software Atoll 3.3 for simulation.

\section{Backhaul Network Topology}

In this LTE network design, the adopted topology is the daisy chain network topology, as depicted in Fig. 2. This topology is a transition from bus topology and ring topology, where the nodes are connected to each other.

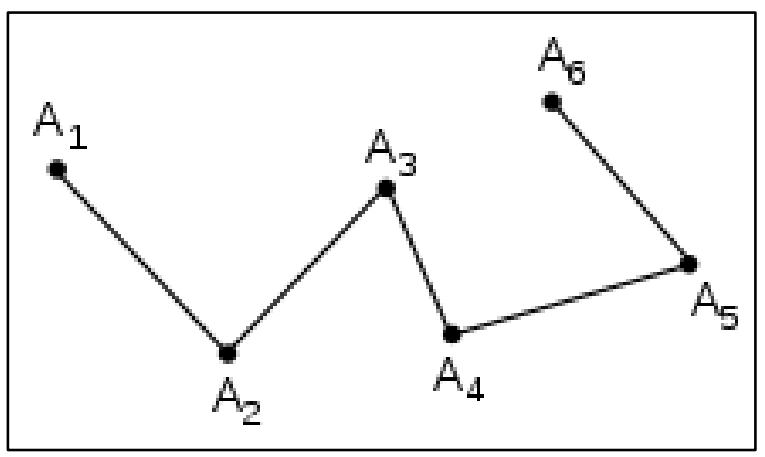

Fig. 2. Daisy Chain Network Topology [5]

Figure 3 shows the hop-to-site link display for backhaul network design. In this design, the topology used is the chain topology, which is for the VillaBNTR site as the main site or as a traffic collector site to proceed to the Core Network. 


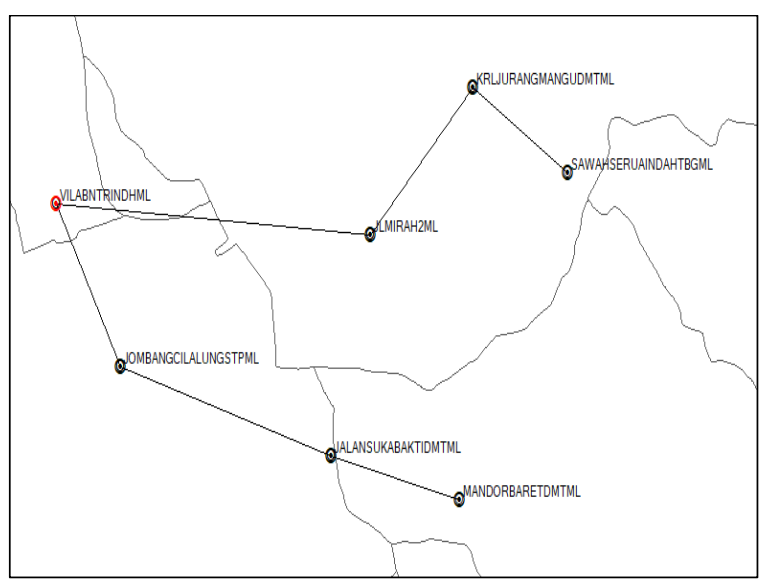

Fig. 3. Link Hop of Backhaul Network

\section{E. Parameter of Capacity Planning}

a) User Estimated Number

Calculation of the user estimated number is by the following equation [6]:

$P_{n}=P_{o}(1+G F)^{n}$

Total User $=$

$P_{n} \times$ User percentage $\times$ Market Share Operator $\times$ Penetration LTE

b) Throughput of Service

To estimate the throughput on the LTE using the throughput on each service as in the following equation (3) [6]:

Throughput=

Session Time $\times$ Session Duty Ratio $\times$ Bearer Rate $\times\left[\frac{1}{(1-B L E R)}\right]$

c) Single-User Throughput (SUT)

Single-user throughput is a user parameter in the use of several available LTE services. Single-user throughput calculation is on the equation (4) [6]:

SUT

$=\frac{\left[\sum\left(\frac{\text { throughput }}{\text { session }}\right) \times B H S A \times \text { penetration ratio } \times(1+\text { peak to average ratio })\right]}{3600}$

d) Network Throughput Calculation

Network throughput is a calculation to find out the number of traffic needs of users in a predetermined area. Network throughput calculations are in the following equation [6]:

Network Throughput $D L=$ total user number $x$ DL single user throughput

Network Throughput $U L=$

total user number $x$ UL single user throughput

\section{e) Cell Capacity}

Calculation of this cell capacity obtained from the LTE system, both uplink and downlink [6]:

$D L$ cell capacity $+C R C$

$=(168-36-12) \times(C b) \times N r b \times C \times 1000$
$U L$ cell capacity $+C R C$

$=(168-24) \times(\mathrm{Cb}) \times(\mathrm{Cr}) \times \mathrm{Nrb} \times \mathrm{C} \times 1000$

f) Cell Average Throughput

The cell average throughput calculation is used to get the average cell capacity values for all modulation, in the uplink and downlink side [6]:

Cell Average Throughput $(M A C)=$ Total $P_{n} \times R_{n}$ (9)

Site Capacity $=$ Cell Average Throughput $\times 3$

g) Number of eNodeB

The calculation of the number of eNodeB can be determined based on the planned area and number of customers in the area. Calculation of the number of eNodeB uses the following equation [6]:

Number of eNodeB $=\frac{\text { Network } \text { Throughput }}{\text { Site Capacity }}$

h) Effective Isotropic Radiated Power (EIRP)

EIRP is the maximum power of microwaves that emit from the transmitter antenna and use to show the effective value of the power emitted by the transmitter antenna. To obtain EIRP values, we use the following equation [7]:

$E I R P=P_{T X}+G_{\text {Antenna }}-L_{T x}$

i) Availability

Availability is a measure of the reliability of a system in providing services. Ideally, a system must have $100 \%$ availability. The opposite of availability is una vailability or outage time, which is a system failure in providing services. The availability and unavailability values obtained by using these following equations [7]:

Availability $=(1-$ unAvailability $) \times 100 \%$

UnAvailability $=a \times b \times 2.5 \times f \times D^{3} \times 10^{-6} \times 10^{\frac{F M}{10}}$

j) Quality Objective

The quality of the communication system is measured based on the parameters Bit Error Ratio (BER) and data rate. In order to achieve the desired BER and data rate, the Carrier to Noise $(\mathrm{C} / \mathrm{N})$ value on the receiver side has to meet this equation [1]:

$\frac{C}{N} r e q=\frac{E b}{N o}+\frac{R}{B W}-C G+M I$

With CG is coding gain and $\mathrm{MI}$ is margin implementation.

\section{RESULT}

This research discusses the comparison of backhaul network performance between 802.11ac and microwave for LTE networks in urban areas.

\section{A. Calculation of User Estimated Number}

By using (1) and (2) an estimated number of users is 90,167 users, as in the following calculation:

$P_{n}=P_{o}(1+G F)^{\mathrm{n}}$

$P_{n}=239,152(1+0,0317)^{5}=279,538$ 
Total User $=$

$P_{n} \times$ User percentage $\times$ Market Share Operator $\times$ Penetration LTE

Total User $=279,538 \times 0.72 \times 0.56 \times 0.80$

Total User $=90,167$ users

\section{B. Calculation of User Throughput}

The calculation of throughput from file transfer services in the downlink and uplink based on Table 1, while the overall value of a single user throughput for some services in the uplink or downlink as in the Table 2.

Table 1. Throughput/Session

\begin{tabular}{lcc}
\hline Traffic Parameter & UL & DL \\
\cline { 2 - 3 } & $\begin{array}{c}\text { Throughput/ } \\
\text { session(Kbit) }\end{array}$ & $\begin{array}{c}\text { Throughput / } \\
\text { Session(Kbit) }\end{array}$ \\
\hline VoIP & 869.49 & 869.49 \\
Video Phone & 4421.31 & 4421.31 \\
Video Conference & 113690.91 & 113690.91 \\
Real Timr Gaming & 11367.28 & 90952.72 \\
Streaming Media & 5683.64 & 22737.27 \\
IMS Signaling & 22.10 & 22.10 \\
Web Browsing & 5684.54 & 22737.27 \\
File Transfer & 85266.67 & 454751.52 \\
Email & 7105.55 & 11368.78 \\
P2P File Sharing & 303163.63 & 909503.03 \\
\hline
\end{tabular}

Table 2. Single-User Throughput

\begin{tabular}{lcc}
\hline \multirow{2}{*}{ Traffic Parameters } & \multicolumn{2}{c}{ Urban } \\
\cline { 2 - 3 } & UL (Kbps) & $\begin{array}{c}\text { DL } \\
\text { (Kbps) }\end{array}$ \\
\hline VoIP & 0.377 & 0.377 \\
Video Phone & 0.047 & 0.047 \\
Video Conference & 0.853 & 0.853 \\
Real Time Gaming & 0.151 & 1.213 \\
Streaming Media & 0.042 & 0.170 \\
IMS Signaling & 0.009 & 0.009 \\
Web Browsing & 0.758 & 3.032 \\
File Transfer & 1.136 & 6.063 \\
Email & 0.071 & 0.114 \\
P2P File Sharing & 6.063 & 18.190 \\
Total Single-user & $\mathbf{9 . 5 0 7}$ & $\mathbf{3 0 . 0 6 8}$ \\
Throughput (Kbps) & &
\end{tabular}

\section{Calculation of Link Capacity}

In backhaul network design, the designed capacity of each link is must be known. In this backhaul network design, site capacity that used in the calculation is to use the largest site capacity on the uplink of $60,65 \mathrm{Mbps}$ or about $61 \mathrm{Mbps}$.
Table 3. Total Site Calculation

\begin{tabular}{|c|c|c|}
\hline \multirow{2}{*}{ Parameters } & \multicolumn{2}{|c|}{ Urban } \\
\hline & Uplink & Downlink \\
\hline Total Target User & \multicolumn{2}{|c|}{90,167} \\
\hline Network Throughput (Mbps) & 85.721 & 271.114 \\
\hline $\begin{array}{l}\text { Cell Average Throughput } \\
\text { (MAC) }\end{array}$ & 20.22 & 16.85 \\
\hline Site Capacity (Mbps) & 60.65 & 50.54 \\
\hline Number of eNodeB & 1 & 5 \\
\hline
\end{tabular}

Table 4. Link Capacity

\begin{tabular}{lllllll}
\hline & \multirow{2}{*}{$\begin{array}{c}\text { Route } \\
\text { Path }\end{array}$} & $\begin{array}{c}\text { Site } \\
\text { Capacity }\end{array}$ & & \multicolumn{4}{c}{ Link Capacity } \\
\cline { 5 - 7 } & & & Lv-n & Lv-1 & Lv-2 & Lv-3 \\
\hline 1 & 3 & 61 & 427 & & & \\
2 & $3 \sim 2$ & 61 & & 183 & & \\
3 & $3 \sim 2 \sim 1$ & 61 & & & 122 & \\
4 & $3 \sim 2 \sim 1 \sim 0$ & 61 & & & & 61 \\
5 & $3 \sim 4$ & 61 & & 183 & & \\
6 & $3 \sim 4 \sim 5$ & 61 & & & 122 & \\
7 & $3 \sim 4 \sim 5 \sim 6$ & 61 & & & & 61 \\
\hline
\end{tabular}

Table 3 is a site numbering that shows the representation of site information in the Ciputat Subdistrict area. Following is an example calculation of the link capacity in route path 3 to $4(3 \sim 4)$ from Table 4.

$$
\begin{aligned}
\mathrm{Lv}_{1} & =\mathrm{Lv}_{3}+\mathrm{Lv}_{2} \\
& =61+122=183 \mathrm{Mbps} .
\end{aligned}
$$

Based on the calculation results, the obtained capacity for the 3 4 link is $183 \mathrm{Mbps}$. It consists of a link capacity of $5 \sim 6$ for $61 \mathrm{Mbps}$ and a link of $5 \sim 4$ for $122 \mathrm{Mbps}$. So, the total amount of link capacity needed to distribute data traffic to the core network that is equal to $427 \mathrm{Mbps}$.

\section{DISCUSSION}

In the backhaul network design using microwave technology, the operating frequency is $18 \mathrm{GHz}$, while for Wi-Fi is $5 \mathrm{GHz}$. In this simulation, the data traffic capacity must achieve $427 \mathrm{Mbps}$.

Based on the simulation results, the EIRP value between microwave and Wi-Fi has a difference. The EIRP value on the microwave backhaul has a higher value than the EIRP value on the Wi-Fi backhaul. This is because the frequency used in microwave backhaul is higher than the rate used in the Wi-Fi backhaul. In addition, the parameter that can affect the value of the EIRP is the antenna diameter. In this study, microwave backhaul using $0.6 \mathrm{~m}$ diameter antenna, while for Wi-Fi backhaul using $3.8 \mathrm{~m}$. In Table 5, the EIRP results from microwave are greater than EIRP backhaul Wi-Fi. Related to those outputs, 
the larger the antenna diameter, the greater the EIRP value.

Table 5. Simulation Result on EIRP

\begin{tabular}{lcccc}
\hline \multicolumn{1}{c}{ Hop } & \multicolumn{2}{c}{ EIRP Microwave } & \multicolumn{2}{c}{ EIRP Wi-Fi } \\
\cline { 2 - 5 } & A to B & B to A & A to B & B to A \\
\hline $\begin{array}{l}\text { SawahSeruai - } \\
\text { KRLJurang }\end{array}$ & 53.25 & 49.96 & 44.86 & 44.83 \\
$\begin{array}{l}\text { KRLJurang - } \\
\text { JLMirah }\end{array}$ & 50.26 & 50.16 & 44.24 & 44.24 \\
$\begin{array}{l}\text { JLMirah - } \\
\text { VillaBNTR }\end{array}$ & 54.98 & 54.98 & 44.43 & 44.66 \\
$\begin{array}{l}\text { SawahSeruai - } \\
\text { KRLJurang }\end{array}$ & 52.69 & 51.57 & 44.75 & 44.64 \\
$\begin{array}{l}\text { KRLJurang - } \\
\text { JLMirah }\end{array}$ & 55.59 & 54.98 & 44.76 & 44.64 \\
$\begin{array}{l}\text { JLMirah - } \\
\text { VillaBNTR }\end{array}$ & 53.49 & 49.96 & 44.64 & 44.6 \\
$\begin{array}{l}\text { SawahSeruai - } \\
\text { KRLJurang }\end{array}$ & 53.25 & 49.96 & 44.86 & 44.83 \\
\hline
\end{tabular}

The main parameters in backhaul links design using microwave and $\mathrm{Wi}-\mathrm{Fi}$ technology are availability and quality-objective values. For both techniques, the standard availability value must achieve $99.999 \%$. The quality objectives based on the performance standard that must be made in the microwave are $-57 \mathrm{dBm}$. Meanwhile, for $\mathrm{Wi}-\mathrm{Fi}$, the quality objectives goal is $-72 \mathrm{dBm}$.

Table 6 and 7 show the simulation results on the availability value and results on received signal level (RSL) using microwave and Wi-Fi.

Table 6. Simulation Results on Availability Value

\begin{tabular}{|c|c|c|c|}
\hline \multirow{2}{*}{ Hop } & \multirow{2}{*}{$\begin{array}{c}\text { Availability } \\
\text { Objective } \\
(\%)\end{array}$} & \multicolumn{2}{|c|}{ Availability (\%) } \\
\hline & & Microwave & $W i-F i$ \\
\hline $\begin{array}{l}\text { SawahSeruai - } \\
\text { KRLJurang }\end{array}$ & 99.999 & 99.999668 & 100 \\
\hline $\begin{array}{l}\text { KRLJurang - } \\
\text { JLMirah }\end{array}$ & 99.999 & 99.998258 & 100 \\
\hline $\begin{array}{l}\text { JLMirah - } \\
\text { VillaBNTR }\end{array}$ & 99.999 & 99.994218 & 100 \\
\hline $\begin{array}{l}\text { VillaBNTR - } \\
\text { Jomblang }\end{array}$ & 99.999 & 99.99939 & 100 \\
\hline $\begin{array}{l}\text { Jomblang - } \\
\text { JLSukabakti }\end{array}$ & 99.999 & 99.997592 & 100 \\
\hline $\begin{array}{l}\text { JLSukabakti - } \\
\text { Mandor Baret }\end{array}$ & 99.999 & 99.999446 & 100 \\
\hline \multicolumn{2}{|c|}{ Average Availability } & $99.998095 \%$ & $100 \%$ \\
\hline
\end{tabular}

Table 7. Simulation Results on Received Signal Level

\begin{tabular}{lcccc}
\hline \multirow{2}{*}{ Hop } & \multicolumn{2}{c}{ Microwave } & \multicolumn{2}{c}{ Wi-Fi } \\
\cline { 2 - 5 } & $\begin{array}{c}\text { Quality } \\
\text { Objective } \\
(\mathbf{d B m})\end{array}$ & $\begin{array}{c}\text { RSL } \\
(\mathbf{d B m})\end{array}$ & $\begin{array}{c}\text { Quality } \\
\text { Objective } \\
(\mathbf{d B m})\end{array}$ & $\begin{array}{c}\text { RSL } \\
(\mathbf{d B m})\end{array}$ \\
\hline $\begin{array}{l}\text { Sawah Seruai - } \\
\text { KRLJurang }\end{array}$ & -57 & -31.17 & -72 & -38.24 \\
$\begin{array}{l}\text { KRLJurang - } \\
\text { JLMirah }\end{array}$ & -57 & -36.35 & -72 & -41.66 \\
$\begin{array}{l}\text { JLMirah - } \\
\text { VillaBNTR }\end{array}$ & -57 & -35.10 & -72 & -47.62 \\
$\begin{array}{l}\text { VillaBNTR - } \\
\text { Jomblang }\end{array}$ & -57 & -31.84 & -72 & -40.15 \\
Jomblang - & -57 & -29.68 & -72 & -44.45 \\
JLSukabakti & & & & -40.23 \\
JLSukabakti - & -57 & -34.70 & -72 & \\
MandorBaret & & & & \\
Average RSL & $\mathbf{- 3 3 . 1 4} \mathbf{d B m}$ & $\mathbf{- 4 2 . 0 6} \mathbf{d B m}$ \\
\hline
\end{tabular}

In all link that has been designed using microwave technology, the average RSL value obtained is -33.14 $\mathrm{dBm}$. This value meets the quality objectives because the RSL value obtained from the simulation has a value higher than the value of the quality objectives that have been determined by a calculation that is -57 $\mathrm{dBm}$. In Wi-Fi technology, the average RSL value obtained is $-42,06 \mathrm{dBm}$. This RSL value has met the quality objectives standard because the RSL value obtained is higher than the value of the quality objectives determined by the calculation, which is -72 $\mathrm{dBm}$.

\section{CONCLUSSION}

Based on the results, it can be concluded that the calculation of the capacity of total target users is 90,167 users. Meanwhile, the number of eNodeB on the downlink side is five sites. The RSL value obtained from the microwave-based is $-57 \mathrm{dBm}$, better than the Wi-Fi-based of $-72 \mathrm{dBm}$. From the simulation results, the average a mount of a vailability on microwave technology is $99.998095 \%$, while for Wi-Fi technology is $100 \%$. Based on a comparison of the two techniques, the microwave with a frequency of $18 \mathrm{GHz}$ and the Wi-Fi with $5 \mathrm{GHz}$, from the standard value of the performance on the backhaul networks, it concludes that the Wi-Fi technology is more appropriate as a backhaul network in Ciputat Sub-district area.

\section{REFERENCES}

[1] A. S. Yogapratama, "Analisis perancangan terhadap perfomansi backhaul berbasis wi-fi 802.11n untuk mendukung jaringan LTE di daerah rural," in Proceeding of Engineering, vol. 2, 2015

[2] Muchlisin, H. Wijanto, Hafidudin, "Perencanaan capacity coverage pada access link dan backhaul menggunakan minilink pada jaringan lte di daerah kota 
Bandung," in e-Proceeding of Engineering: vol. 4, p. 146, 2017.

[3] Intan,Tri Widyawati, "Perancangan jaringan backhaul untuk sistem komunikasi $4 \mathrm{G}$ long term evolution (LTE) di Jakarta area Kalideres" Undergraduate Thesis thesis, Institut Teknologi Telkom Purwokerto, 2017.

[4] Kecamatan Ciputat Dalam Angka 2018, Tangerang Selatan: Badan Pusat Statistik Kecamatan Ciputat, 2018.

[5] Gueabans, "Topologi jaringan komputer," 07 November 2017. [Online]. Available: https://www.gueabans.com/2017/11/topologi-jaringankomputer-bus.html.

[6] L. Mobile Comm, "Carrier aggregation strategy for LTE advanced radio network planning" Undergraduate Thesis, Universitas Telkom, Bandung, 2014.

[7] A. Hikmaturokhman, E. Wahyudi, and H. Sulaiman, "Analisa pengaruh interfrensi terhadap availability pada jaringan transmisi microwave menggunakan software PATHLOSS 5.0 kasus di pt. alita praya mitra," ECOTIPE, vol. 1, no. 13, 2014. 